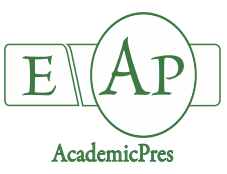

Grigoriadou K et al. (2021)

Notulae Botanicae Horti Agrobotanici Cluj-Napoca

Volume 49, Issue 1, Article number 12168

DOI:10.15835/nbha49112168

Research Article

\title{
Propagation and ex-situ conservation of Lomelosia minoana subsp. minoana and Scutellaria hirta - two ornamental and medicinal Cretan endemics (Greece)
}

\author{
Katerina GRIGORIADOU*, Nikos KRIGAS, \\ Virginia SARROPOULOU, Eleni MALOUPA, \\ Georgios TSOKTOURIDIS
}

\begin{abstract}
Hellenic Agricultural Organization (HAO)-DEMETER, Institute of Plant Breeding and Genetic Resources, Balkan Botanic Garden of Kroussia, Laboratory of Protection and Evaluation of Native and Floriculture Species, GR-570 01 Thermi, Thessaloniki, P.O. Box 60458,Greece; kgrigoriadou@ipgrb.gr ('correspondingauthor);nikoskrigas@gmail.com; vsarrop@gmail.com; maloupa@bbgk.gr; gtsok1@yahoo.co.uk
\end{abstract}

\begin{abstract}
Human needs and concomitant commercial trade to date trigger the demand of new ornamental plants and new natural medicinal products. The current study includes preliminary seed germination trials and presents the development of effective vegetative propagation protocols for Lomelosia minoana subsp. minoana (Dipsacaceae) and Scutellaria hirta (Lamiaceae), both globally rare, local endemics of Crete (Greece) with potential ornamental and medicinal value. Based on material collected directly from the wild, seed germination was succeeded (38\%, $\left.\mathrm{T}_{50}: 10.74\right)$ only for $L$. minoana subsp. minoana. The optimal indole-3-butyric acid concentrations for effective rooting of cuttings were $2000 \mathrm{mg} \mathrm{L}^{-1}$ for L. minoana subsp. minoana (85\%) and $4000 \mathrm{mg} \mathrm{L}^{-1}$ for $S$. hirta (50\%). Seasonal differences were observed in respective rooting rates of the studied taxa. The detected rooting rates for $L$. minoana subsp. minoana cuttings are above standards to allow possible commercial application in the ornamental industry. Although the detected rooting rate (50\%) for S. hirta was adequate for its ex situ conservation, it seems almost marginal for future commercial application and further investigation is needed. The sustainable utilization of these Cretan endemics studied herein provides new input for the ornamental-horticultural and cosmetic-pharmaceutical industries. This study shows how rare and endemic wild plant species can be progressively domesticated and introduced into sustainable cultivation systems in order to avoid the depletion of unique phytogenetic resources.
\end{abstract}

Keywords: cuttings; floriculture; germplasm preservation; phytogenetic resources; rooting; seed germination; sustainable utilization

\section{Introduction}

The medicinal and horticultural industries are in continuous search for new natural products and new floricultural or ornamental crops. This trend is coupled to date with the need for ecological plantings, landscaping with native plants (Beck, 2013), sustainable landscaping (Antrop, 2006; Ahern, 2013) and

Received: 25 Nov 2020. Received in revised form: 20 Jan 2021. Accepted: 25 Jan 2021. Published online: 22 Feb 2021.

From Volume 49, Issue 1, 2021, Notulae Botanicae Horti Agrobotanici Cluj-Napoca journal will use article numbers in place of the traditional method of continuous pagination through the volume. The journal will continue to appear quarterly, as before, with four annual numbers. 
sustainable exploitation of phytogenetic resources (Krigas and Maloupa, 2008; Maloupa et al., 2008). In the frame of sustainability and modern consumerism addressing commercial/economic needs, such driving forces have triggered to date many contemporary studies focusing on many plant groups which are native across different scales.

From an ornamental/horticultural point of view, members of the genus Lomelosia (including the closely related Scabiosa) of the Dipsacaceae family have been dynamically introduced in ornamental horticulture as new flower crops, such as L. caucasica (M. Bieb.) Greuter \& Burdet (Beisheim and Otte, 2017); as xerophytes in landscaping such as L. crenata (Cirillo) Greuter \& Burdet subsp. dellaportae (Boiss.) Greuter \& Burdet (Krigas et al., 2017), L. graminifolia (L.) Greuter \& Burdet (Barth, 2020), L. hymettia (Boiss. \& Spruner) Greuter \& Burdet and L. cretica (L.) Greuter \& Burdet (Papafotiou et al., 2017b); for use on green roof plantations such as L. prolifera (L.) Greuter \& Burdet (Cristaudo et al., 2015). Amongst $>300$ species in the genus Scutellaria of Lamiaceae family (Joshee et al., 2002), some members have been used in landscaping for harboring ecosystem diversity (Joshee et al., 2013); as ornamental plants or as new flower crops (Cantor et al., 2009; Morgan and Pearson, 2018); in plantations of green roofs such as $S$. wrightii A. Gray (Getter and Rowe, 2008), S. scordifolia (Schltdl. \& Cham.) Benth. (Schneider et al., 2014) and S. pontica K. Koch (Sari and Karaşah, 2015); for xeriscaping such as S. pontica (Sari and Karaşah, 2015), S. rupestris Boiss. \& Heldr. (Maloupa et al., 2005) and S. alpina L. (Calhoun, 2012).

Successful propagation in members of Lomelosia has been reported both via seeds and vegetative methods. Propagation with cuttings for $L$. hymettia using IBA results to a high rate of rooting (92.5-100\%) during autumn, compared to 50-67.5\% during experimentation in spring (Vlachou et al., 2019). In vitro propagation has been successfully employed for L. argentea (L.) Greuter \& Burdet (Panayotova et al., 2008) and the closely related Scabiosa comosa Fisch. ex Roem. \& Schult. (=S. tschiliensis Grunning) (Wang et al., 2013). Scabiosa spp. which are closely related with Lomelosia may show as low as 50-53\% germination e.g., $S$. triniifolia Friv. and S. africana L. (SID-Kew), or up to $100 \%$ in S. canescens Waldst. Kit. (Csonthos et al., 2007) and S. columbaria L. (Cerabolini et al., 2003).

With increased annual consumption of scullcaps (Scutellaria spp.) during the last decades (Greenfeild and Davies, 2004), there is a high need for pathogen-free biomass production of these ornamental and medicinal plants at least in the USA (Tascan et al., 2010). In general, seed germination, cuttings and root division are the main propagation methods for members of Scutellaria (Similien, 2009). In addition, successful propagation through in vitro techniques has been reported (Joshee et al., 2002; Tascan et al., 2010). Advanced propagation systems in vitro have been developed to study model-members of the genus Scutellaria, involving simple shoot proliferation techniques, bioreactors, and gene transformation protocols (Cole et al., 2007, 2009; Joshee et al., 2013). Propagation of Scutellaria spp. by seeds can be highly successful and fast (100\% germination within 8 days for $S$. pycnoclada Juz. and S. tomentosa Bertol.), intermediate and rather slow, 52\% within 42 days for $S$. ramosissima Popov (SID-Kew) or slow with very low success, $10 \%$ within a month for $S$. incana Spreng. (O’Brien, 2013).

With regards to medicinal interest, most species of genus Scutellaria are usually rich in scutellarin, a substance with anti-cancer activity and for treatment of cardiovascular diseases (Cui et al., 2010), and they contain essential oils and phenolic compounds with antioxidant, anti-carcinogenic, anti-mutagenic, antibacterial and anti-inflammatory action (Heo et al., 2004). L. hymettia is also considered as a medicinal plant (Grigoriadou et al., 2019) with antimicrobial properties (Christopoulou et al., 2008).

In this study we focused on Greek native rock-dwelling plants which are globally rare and exclusively confined to the island of Crete (local single-island endemics). Additionally, the focal herbaceous perennial plants studied have useful medicinal properties as well as interesting features and natural adaptations that could be exploited in floriculture, horticulture, and landscaping. Such features refer to seasonal colour variations as in Scutellaria hirta Sm.; impressive inflorescence (compound heads of many lingulate florets) combined with vigorous growth and natural adaptation to arid conditions allowing (among others) for use as ground cover as in Lomelosia minoana (P. H. Davis) Greuter \& Burdet subsp. minoana. The combination of rarity, uniqueness, 
usefulness and impressive plant features or adaptations are known to be extremely appreciated by the international online floricultural-ornamental market (Dee et al., 2019) and consequently such endemic native plants are usually associated with high prices (Krigas et al., 2014; Menteli et al., 2019).

In this context, the vegetative and sexual propagation of the selected plants are studied herein for the first time with the aim to facilitate their ex situ conservation and further sustainable exploitation as valuable and unique phytogenetic resources of Greece in the global context.

\section{Materials and Methods}

\section{From botanical collections in the wild to stock mother plants for experimentation}

Two botanical collections were performed on the island of Crete (Greece) during late summer (end of August) and autumn (mid-October) of 2018 using a special permit of the Balkan Botanic Garden of Kroussia (BBGK), which is issued yearly by the Greek Ministry of Environment and Energy (renewed every year). The selected plant material (young individuals, seeds, and cuttings) was collected carefully in order to avoid any damage to the extant wild growing populations of the taxa (species and subspecies) and was transferred to the facilities of the BBGK in Thermi, Thessaloniki, where finally received an IPEN (International Plant Exchange Network) accession number after taxonomical identification (Table 1).

The living plants collected from the wild (Table 1; Figure 1) in Crete were transplanted and maintained in a greenhouse.
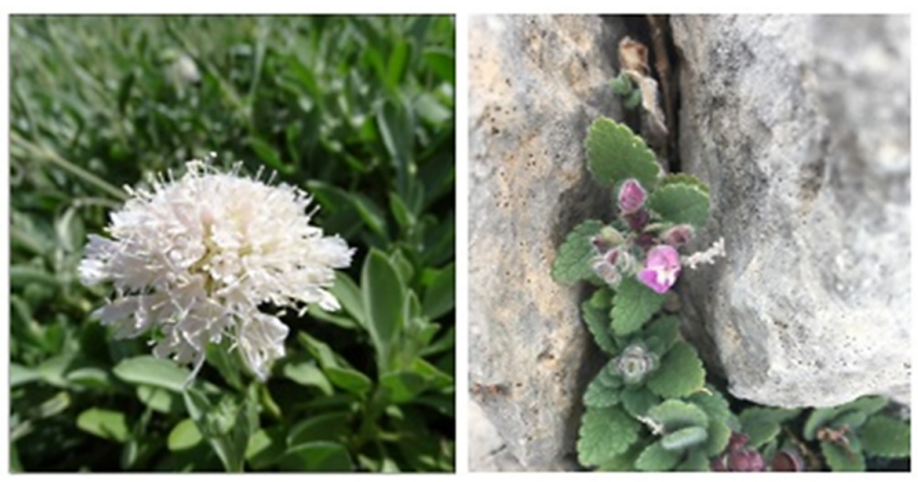

Figure 1. Mature individuals of Lomelosia minoana subsp. minoana (left) and Scutellaria hirta (right) in their wild habitats at mountain areas on the island of Crete, Greece

A month later, shoot tip cuttings were excised from the collected plants, were treated with $2000 \mathrm{mg} \mathrm{L}^{-1}$ indole-3-butyric acid (IBA) (Radicin, Fytorgan SA, Greece), were transferred in multi-cell propagation trays using a substrate mixture of peat moss (Terrahum, Klasmann): perlite $(1: 3 \mathrm{v} / \mathrm{v})$ and were placed under mist in $80-90 \%$ relative humidity $(\mathrm{RH})$. Three weeks later, the rooted cuttings were transplanted in $1 \mathrm{~L}$ plastic pots. This procedure was repeated every month from September 2018 until February 2019, allowing the production of adequate stock material for experimentation.

The cuttings collected from the wild grown plants (Table 1) were initially kept in a fridge, they were transported using a portable one to the BBGK's laboratory and were treated with the same rooting procedure described previously. The inflorescences collected from the wild-growing plants were placed for drying in a dark chamber at $15{ }^{\circ} \mathrm{C}$ and $\mathrm{RH} 15 \%$ and one month later, the seeds were separated and weighed, determining the average weight of ten seeds (Table 1). The cleaned seeds were used in experimentation. Cuttings and young wild individual plants were collected for $S$. hirta, because the season was not appropriate for seed collection. 
Table 1. Basic information about the original plant material (seeds, cuttings, living individuals) of the local Cretan endemics collected from the natural environment of the island of Crete (Greece) for ex situ conservation in the Balkan Botanic Garden of Kroussia

\begin{tabular}{|c|c|c|c|c|c|}
\hline $\begin{array}{c}\text { Taxon } \\
\text { (IPEN accession number) }\end{array}$ & $\begin{array}{c}\text { Geographical } \\
\text { areas }\end{array}$ & $\begin{array}{c}\text { No of } \\
\text { seeds }\end{array}$ & $\begin{array}{c}\text { Weight of } 10 \\
\text { seeds }(\mathrm{mg})\end{array}$ & $\begin{array}{c}\text { No of } \\
\text { cuttings }\end{array}$ & $\begin{array}{c}\text { No of } \\
\text { individuals }\end{array}$ \\
\hline $\begin{array}{c}\text { Lomelosia minoana } \\
\text { subsp. minoana } \\
(\text { GR-1-BBGK-19,16) }\end{array}$ & Ano Viannos & 1500 & 60 & 132 & 1 \\
\hline $\begin{array}{c}\text { Scutellaria hirta } \\
\text { (GR-1-BBGK-19,3) }\end{array}$ & Skinakas & - & - & 30 & 1 \\
\hline
\end{tabular}

\section{Seed germination}

Seed germination was determined in autumn (November 2018) right after their collection. The seeds ( $\mathrm{n}=50$ for L. minoana subsp. minoana) were saturated in di-ionized water $\left(\mathrm{dH}_{2} \mathrm{O}\right)$ for $24 \mathrm{~h}$ and were then sowed ( $4-5 \mathrm{~mm}$ depth) in plastic trays containing a substrate of peat (Terrahum, Klassman): perlite $(1: 1 \mathrm{v} / \mathrm{v})$ covered with a layer of vermiculite $(2-3 \mathrm{~mm})$. The trays were placed on a heated-bench mist-chamber $(19 \pm 2$ ${ }^{\circ} \mathrm{C}$ soil temperature and $\left.80-90 \% \mathrm{RH}\right)$. The seed germination rate was recorded every fortnight for two consecutive months by measuring the number of seeds with visible sprouting and $\mathrm{T}_{50}$ (the time required for $50 \%$ germination of the final germination rate of the seeds) was calculated (Bewley and Black, 1994; Genmedoc, 2006). After seed germination and growth for $60 \mathrm{~d}$, the seedlings were transferred in multiple cell propagation trays and followed the procedure described below for rooted plants.

\section{Rooting of cuttings}

The rooting of cuttings obtained from mother stock plants were treated with four different concentrations $\left(0,1000,2000\right.$ and $\left.4000 \mathrm{mg} \mathrm{L}^{-1}\right)$ of IBA (Duchefa Biochemie, The Netherlands) during JuneJuly 2019. Softwood tip cuttings of L. minoana subsp. minoana $(3-4 \mathrm{~cm})$ and $S$. hirta $(3.5-4 \mathrm{~cm}$ long) were immersed for $10 \mathrm{sec}$ in the above IBA solutions (dissolved in 50\% ethanol), were transferred in multi-cell propagation trays using a $1: 3 \mathrm{v} / \mathrm{v}$ peat moss (TS1, Klasmann): perlite substrate and were placed in a mist chamber (soil temperature $18-25^{\circ} \mathrm{C}$, air temperature $18-30^{\circ} \mathrm{C}$ depending on local weather conditions, and $\mathrm{RH}$ $70-85 \%$ ) within the BBGK's non-heated greenhouse. The number of roots per cutting and root length was measured for L. minoana subsp. minoana after $40 \mathrm{~d}$ and for $S$. hirta after $15 \mathrm{~d}$. The rooting of cuttings was expressed as percentage. Rooted plants from all the above treatments were transplanted in $0.33 \mathrm{~L}$ pots and subsequently in $2.5 \mathrm{~L}$ after four weeks, containing a mixture of peat (TS2, Klasmann) and perlite $(3: 1 \mathrm{v} / \mathrm{v})$ for further growth. The excess plant material produced was planted for long-term ex situ conservation in special garden beds at the BBGK's sea level and mountain facilities (botanic gardens in Thermi, prefecture of Thessaloniki and in Pontokerassia, prefecture of Kilkis at $650 \mathrm{~m}$ altitude). One potted mother stock plant of both $L$. minoana subsp. minoana and $S$. hirta was depicted visually under ex situ conservation at the BBGK, each species separately which represent the potential of the two taxa for field cultivation. (Figures $2 c, 3 c$ ).

\section{Statistical analysis}

All rooting experiments were conducted in a completely randomized design and were repeated twice. The means were subjected to analysis of variance (ANOVA) using the statistical package SPSS 17.0 (SPSS Inc, Chicago, Illinois, USA) and were compared by using the Duncan's multiple-range test. The experiments consisted of four treatments where each value was the mean of 21 replicates (three groups of seven repetitions). To compare the means, the Duncan's multiple range test was used at $\mathrm{P} \leq 0.05$ to establish significant differences among the treatments. The main effect of factors (rooting period and IBA concentration) as well as their interaction were determined by the General Linear Model (two-way ANOVA). 


\section{Results}

Vegetative propagation and development of stock mother plants

The cuttings of $L$. minoana subsp. minoana collected from the wild (cuttings from the wild growing plants transferred to the ex situ facilities of BBGK) presented 86-88\% rooting, resulting in a total of 186 stock mother plants. High rooting success $(96-100 \%)$ was achieved for $S$. hirta cuttings obtained from wild-growing individuals, producing a total of 237 plants within seven months (Table 2).

Table 2. Preliminary rooting experiments of cuttings from the Cretan local endemic plants Lomelosia minoana subsp. minoana (September: in situ collected cuttings; February: ex situ collected cuttings) and Scutellaria hirta (all ex situ), originated from wild-growing populations, using $2000 \mathrm{mg} \mathrm{L}^{-1}$ IBA for the initial development of stock clonal mother plants

\begin{tabular}{|c|c|c|c|c|c|c|c|c|c|c|}
\hline & \multicolumn{3}{|c|}{ September 2018} & \multicolumn{3}{|c|}{ October 2018} & \multicolumn{3}{|c|}{ February 2019} & \multirow[b]{2}{*}{ 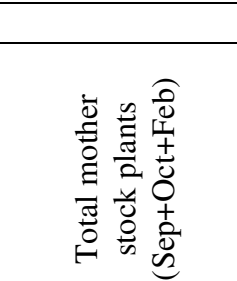 } \\
\hline Taxon & 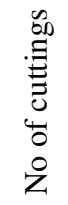 & 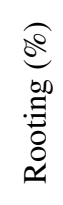 & 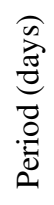 & 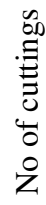 & $\begin{array}{c}\underbrace{20}_{0} \\
\vdots \\
0 \\
0 \\
0 \\
0\end{array}$ & 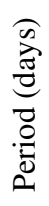 & $\begin{array}{l}\mathscr{n} \\
\stackrel{6}{0} \\
\stackrel{\Xi}{\Xi} \\
0 \\
0 \\
0 \\
0 \\
0 \\
z\end{array}$ & $\begin{array}{l}\underbrace{0}_{00} \\
0 \\
0 \\
0 \\
0 \\
0\end{array}$ & 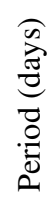 & \\
\hline $\begin{array}{c}\text { Lomelosia minoana } \\
\text { subsp. minoana }\end{array}$ & 132 & 86 & 23 & - & - & - & 84 & 88 & 60 & $186(113+0+73)$ \\
\hline Scutellaria hirta & 24 & 100 & 40 & 54 & 100 & 24 & 166 & 96 & 28 & $237(24+54+159)$ \\
\hline
\end{tabular}

Seed germination

Seed germination for L. minoana subsp. minoana was observed within the first six days (first signs of sprouting). During the first fortnight, $20 \%$ of the seeds germinated and after 30 days, the number of germinated seeds increased to $34 \%$ and reached $38 \%$ in 60 days $\left(\mathrm{T}_{50}=10.74\right)$ (Table 3$)$.

Table 3. Effect of sowing days (15, 30, 45, 60) on germination (\%) of Lomelosia minoana subsp. minoana seeds in peat: perlite $(1: 1 \mathrm{v} / \mathrm{v})$, after pre-treatment in $\mathrm{ddH}_{2} \mathrm{O}$ for $24 \mathrm{~h}$ prior to sowing $(20 / 11 / 2018)$.

\begin{tabular}{|c|c|}
\hline Days after sowing & Germination (\%) \\
\hline 15 & $20 \mathrm{~b}$ \\
\hline 30 & $34 \mathrm{a}$ \\
\hline 45 & $36 \mathrm{a}$ \\
\hline 60 & $38 \mathrm{a}$ \\
\hline$p$-values & $0.009^{* *}$ \\
\hline
\end{tabular}

Different letters between different days of sowing within the Germination (\%) column denote significant differences (Duncan test, $\mathrm{p}>0.05,{ }^{* *} \mathrm{p} \leq 0.01$ ).

\section{Effect of IBA in rooting}

The use of IBA independently of concentration was the best treatment for the vegetative propagation of cuttings in L. minoana subsp. minoana. IBA at $2000 \mathrm{mg} \mathrm{L}^{-1}$ was rather the best treatment considering mean number of roots (17.17) (Table 4; Figure 2). 
Table 4. Effect of different concentrations of IBA on rooting (\%), number and length $(\mathrm{cm})$ of roots obtained from Lomelosia minoana subsp. minoana stock mother plants after $40 \mathrm{~d}$ in mist, using a substrate composed of peat: perlite at $1: 3 \mathrm{v} / \mathrm{v}$

\begin{tabular}{|c|c|c|c|}
\hline Treatments & $\begin{array}{c}\text { Rooting } \\
(\%)\end{array}$ & $\begin{array}{c}\text { Number of roots / } \\
\text { rooted cutting }\end{array}$ & $\begin{array}{c}\text { Root length } \\
(\mathrm{cm})\end{array}$ \\
\hline Control & $42.86 \mathrm{~b}$ & $5.33 \pm 0.48 \mathrm{c}$ & $2.62 \pm 0.43 \mathrm{~b}$ \\
\hline $1000 \mathrm{mg} \mathrm{L}^{-1} \mathrm{IBA}$ & $71.43 \mathrm{a}$ & $14.30 \pm 2.17 \mathrm{ab}$ & $4.42 \pm 0.27 \mathrm{a}$ \\
\hline $2000 \mathrm{mg} \mathrm{L}^{-1} \mathrm{IBA}$ & $85.71 \mathrm{a}$ & $17.17 \pm 2.20 \mathrm{a}$ & $3.61 \pm 0.34 \mathrm{ab}$ \\
\hline $4000 \mathrm{mg} \mathrm{L}^{-1} \mathrm{IBA}$ & $85.71 \mathrm{a}$ & $10.83 \pm 1.58 \mathrm{~b}$ & $4.54 \pm 0.35 \mathrm{a}$ \\
\hline$P$-values & $0.019^{*}$ & $0.000^{* * *}$ & $0.001^{* *}$ \\
\hline
\end{tabular}

Different letters between different IBA concentrations within a column denote significant differences (Duncan test, $\left.\mathrm{p}>0.05,{ }^{*} \mathrm{p} \leq 0.05,{ }^{* *} \mathrm{p} \leq 0.01,{ }^{* * *} \mathrm{p} \leq 0.001\right)$.

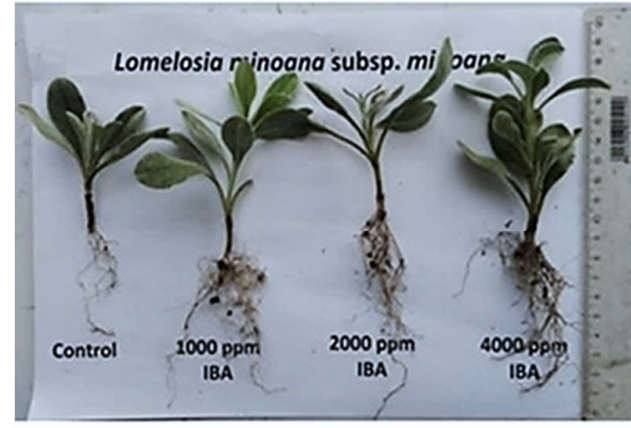

(A)

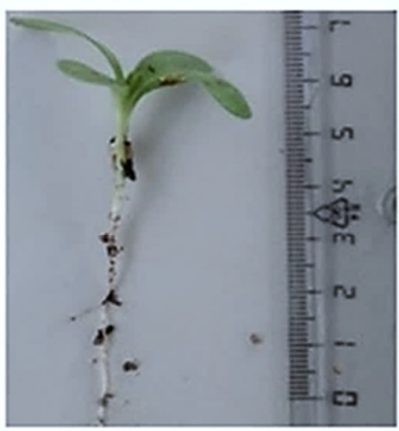

(B)

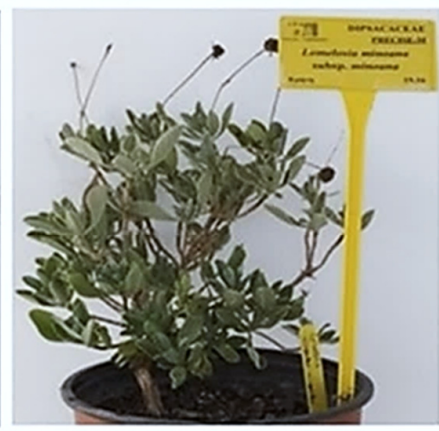

(C)

Figure 2. Effect of IBA $\left(0,1000,2000\right.$ and $\left.4000 \mathrm{mg} \mathrm{L}^{-1}\right)$ on rooting of cuttings of Lomelosia minoana subsp. minoana

(A) after $40 \mathrm{~d}$ under mist using a substrate composed of peat moss (TS1, Klasmann): perlite at 1:3v/v; (B) individual rooted cutting; (C) potted mother stock plant under ex situ conservation at the Balkan Botanic Garden of Kroussia

The best application of IBA was achieved at $4000 \mathrm{mg} \mathrm{L}^{-1}$ in $S$. hirta cuttings, by increasing the rooting percentage from $5.26 \%$ (control) to $52.38 \%$. The two lower IBA concentrations also increased the percentage of rooted cuttings to $22.22 \%$. Symptoms of browning from the base towards the apex of the cuttings were evident in all treatments including the control (19.05-23.81\%) irrespectively of IBA concentration, thus resulting gradually in total necrosis at the end of the experimental rooting period ( $15 \mathrm{~d})$ due to gradual degradation of the cuttings not forming any roots. IBA concentration did not affect root length, since treated cuttings exhibited similar results with the untreated ones $(1.05$ and $0.92 \mathrm{~cm}$, respectively) (Table 5; Figures 3AC).

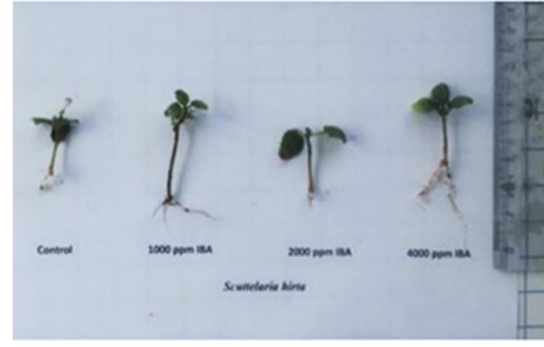

(A)

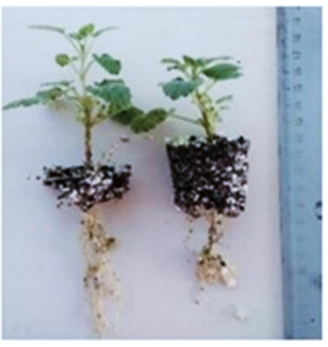

(B)

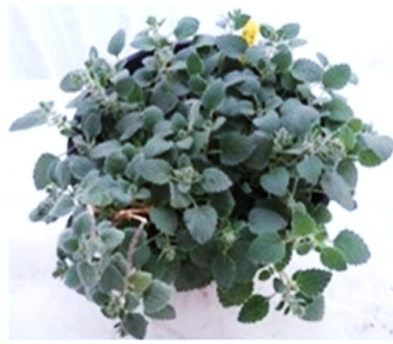

(C)

Figure 3. Effect of IBA $\left(0,1000,2000\right.$ and $\left.4000 \mathrm{mg} \mathrm{L}^{-1}\right)$ on rooting of cuttings of Scutellaria hirta; (A) after $15 \mathrm{~d}$ under mist using a substrate composed of peat moss (TS1, Klasmann): perlite at 1:3 v/v; (B) individual rooted cuttings; (C) potted mother stock plant under ex situ conservation at the Balkan Botanic Garden of Kroussia 
Table 5. Effect of different concentrations of IBA on rooting (\%), number and length $(\mathrm{cm})$ of roots obtained from Scutellaria hirta stock mother plants after $15 \mathrm{~d}$ in mist, using a substrate composed of peat: perlite at $1: 3 \mathrm{v} / \mathrm{v}$

\begin{tabular}{|c|c|c|c|c|}
\hline Treatments & $\begin{array}{c}\text { Rooting } \\
(\%)\end{array}$ & $\begin{array}{c}\text { Number of roots } \\
\text { rooted cutting }\end{array}$ & $\begin{array}{c}\text { Root length } \\
(\mathrm{cm})\end{array}$ & $\begin{array}{c}\text { Necrosis } \\
(\%)\end{array}$ \\
\hline Control & $5.26 \mathrm{c}$ & $6.00 \pm 0.00 \mathrm{a}$ & $0.92 \pm 0.00 \mathrm{ab}$ & $23.81 \mathrm{ab}$ \\
\hline $1000 \mathrm{mg} \mathrm{L}^{-1} \mathrm{IBA}$ & $22.22 \mathrm{~b}$ & $1.75 \pm 0.08 \mathrm{c}$ & $1.05 \pm 0.07 \mathrm{a}$ & $33.33 \mathrm{a}$ \\
\hline $2000 \mathrm{mg} \mathrm{L}^{-1} \mathrm{IBA}$ & $22.22 \mathrm{~b}$ & $1.50 \pm 0.08 \mathrm{c}$ & $0.75 \pm 0.02 \mathrm{~b}$ & $19.05 \mathrm{~b}$ \\
\hline $4000 \mathrm{mg} \mathrm{L}^{-1} \mathrm{IBA}$ & $52.38 \mathrm{a}$ & $3.63 \pm 0.31 \mathrm{~b}$ & $1.05 \pm 0.11 \mathrm{a}$ & $23.81 \mathrm{ab}$ \\
\hline$P$-values & $0.000^{* * *}$ & $0.000^{* * *}$ & $0.003^{* *}$ & $0.044^{*}$ \\
\hline
\end{tabular}

Different letters between different IBA concentrations within a column denote significant differences (Duncan test, $\left.\mathrm{p}>0.05,{ }^{*} \mathrm{p} \leq 0.05,{ }^{* *} \mathrm{p} \leq 0.01,{ }^{* * *} \mathrm{p} \leq 0.001\right)$.

\section{Discussion}

The propagation study of plants with no available data is a tedious and challenging practice in search for the best protocol allowing massive production of elite clonal plants. Our study presents propagation experimentation using seeds and cuttings of the wild Cretan local endemics Lomelosia minoana subsp. minoana and Scutellaria hirta for the first time.

The present study firstly describes preliminary experimentation on germination of seeds collected from the wild growing Cretan endemic $L$. minoana subsp. minoana in autumn right after collection from wild. With germination starting at the $6^{\text {th }} \mathrm{d}$ and T50: $10.71 \mathrm{~d}$, the germination rate was $34 \%$ on $\mathrm{d} 30$, and slightly increased $(38 \%)$ till the end of the experimental period. Low germination rates $(<5 \%$ or $<30 \%)$ were also reported for $L$. graminifolia (Kupferschmid et al., 2000) and Scabiosa atropurpurea indicating the necessity of storage period (ten months under alternating $20 / 10^{\circ} \mathrm{C}$ conditions) to allow increased final germination from approximately $40-50 \%$ (fresh seeds) to $70-80 \%$ (stored ones), thus suggesting innate dormancy and a dormancy-breaking effect (Frischie et al., 2018). In the current study, the mature seeds of $L$. minoana subsp. minoana were directly harvested from the wild $50 \mathrm{~d}$ prior to experimentation, were only saturated for $24 \mathrm{~h}$ in $\mathrm{dH}_{2} \mathrm{O}$ at room temperature in dark, without previous storage in a fridge. The absence of dry storage of its seeds might be the reason for the low germination percentage $(38 \%)$ obtained within a 60 -d period during autumn-winter, indicating a possible occurrence of primary normal dormancy.

The propagation experiments using cuttings for L. minoana subsp. minoana presented $86 \%$ rooting during September in $23 \mathrm{~d}$ and for $S$. hirta $100 \%$ rooting during September within $40 \mathrm{~d}$. The experiments for $L$. minoana subsp. minoana showed no statistical difference on rooting percentage regarding all IBA concentrations used. However, the treatment of $2000 \mathrm{mg} \mathrm{L}^{-1}$ IBA solution was the optimum, producing the highest number of roots (17.17) and $85.71 \%$ rooted plants within $40 \mathrm{~d}$. High induction of roots (100\%) after a two-week period in the mist has been also described for L. hymettia cuttings collected in autumn and winter and treated with $1000 \mathrm{mg} \mathrm{L}^{-1} \mathrm{IBA}$ (Vlachou et al., 2019). Asexual propagation using IBA is also reported in $L$. crenata subsp. dallaportae softwood tip cuttings delivering 60-80\% rooting rates (Krigas et al., 2010). In the case studied herein, IBA presented a promoting effect on rooting (irrespectively of concentration), increased rooting rate (1.66-two-fold) as well as increased number of roots ( 2 to $>3$-fold) and root length $(1-2 \mathrm{~cm})$. In the herbaceous perennial ornamental Scabiosa 'Pink Mist' (closely related to Lomelosia spp.), drench of stem cuttings with 1000 and $3000 \mathrm{mg} \mathrm{L}^{-1}$ IBA solutions as a dip or foliar spray is reported to increase the root number, rooting percentage and rooting area of the generated plants (Hoover, 2018). The effective response of L. minoana subsp. minoana cuttings treated with IBA could be possibly due to the promoting effect of auxins on the root formation process, resulting in high enzyme activity and translocation rate of nutrients from the upper part of the cuttings to their basal ends, which in turn, leads to carbohydrates' hydrolysis, providing enough energy for root cells' formation (Paradikovic et al., 2013). 
The IBA concentration of $4000 \mathrm{mg} \mathrm{L}^{-1}$ was the optimum rooting treatment for $S$. hirta $(52.38 \%$ rooting, 3.63 roots, $1.05 \mathrm{~cm}$ long) within 15 days. This treatment was the highest concentration of IBA used for rooting and the most effective one, with a 10-fold rooting increase compared to control. The abrupt termination of the propagation procedure after 15 days due to infections and degradation of the fragile shoot tips used for cuttings was possibly the reason for the low rooting rate (52.38\%) observed, thus not allowing enough time for a clear IBA effect. This percentage of rooting resulted in the development of a good propagation protocol for conservation purposes regarding $S$. hirta but not good enough for its massive production. Consequently, further experimentation is required using various auxins in different seasonal periods. IBA was selected due to its positive rooting effects in other species of Lamiaceae, resulting to 5-10-fold increase of rooting percentage and number of roots (Venugopal et al., 2018) in Thymbra capitata (L.) Cav., Thymus serpyllum L. and T. vulgaris L. (Iapichino et al., 2006).

Seasonal differences were observed regarding the Cretan local endemics studied during the experimentation for the development of vegetative propagation protocols using cuttings. The experiments performed during summer resulted to lower rooting percentage compared to the autumn and winter treatments. The mother stock plants were maintained in controlled environmental conditions and the cuttings obtained from them were characterized as juvenile fast-growing apical shoots. The use of such juvenile shoots for cuttings may increase the rooting rate as has been extensively reported in the literature and the same observed for hardwood cuttings (Ferreira et al., 2010; Pijut et al., 2011; Beemnet and Solomon, 2012; Denaxa et al., 2012; Wendling et al., 2014b; Elhaak et al., 2015). Another factor affecting rooting (perhaps also associated with the current study) is the age of stock plant material used for the cuttings. It is known that aged plant material (such as the well-developed mature plants from which we excised the cuttings in the wild) tends to be less responsive to the application of IBA in comparison to cuttings obtained from younger plants, which are more responsive to IBA application in terms of root length (Pijut et al., 2011).

In this study, only shoot tip cuttings were used as the ideal cutting type for successful vegetative propagation. The juvenile softwood tip cuttings used in the experimentation process were excised during the end of May or end of August, after continuous pruning of the upper vegetative part of the mother stock plants throughout the previous winter and spring. The reason for this choice is that tip cuttings exhibit higher rooting rates than stem (decapitated) cuttings and this could be attributed to the hypothesis previously reported by Sabatino et al. (2014), suggesting that the endogenous auxin IAA (being basipetally transferred from the apex meristems) plays an essential role in the formation of adventitious roots even when an exogenous auxin type (IBA, NAA, IAA) is also applied. However, root induction of cuttings during vegetative propagation is a complex and multifactorial procedure, where different basic parameters should be optimized for the massive production of elite clonal plants.

The amount of exogenous auxin for rooting induction, initiation, and expression (De Almeida et al., 2017) depends on the species studied and the concentration of auxins present in plant tissues (Paulus et al., 2016). For example, in both Rosmarinus officinalis L. (Paulus et al., 2016) and Aloysia triphylla Paláu (Paulus et al., 2014) the use of higher amounts than $2500 \mathrm{mg} \mathrm{L}^{-1}$ and $1500 \mathrm{mg} \mathrm{L}^{-1}$ of IBA, respectively, is reported to diminish the percentage of rooted cuttings. L. minoana subsp. minoana was proved to require low IBA concentration $\left(2000 \mathrm{mg} \mathrm{L}^{-1}\right)$ for the highest rooting rate in comparison to $S$. hirta that needs higher IBA concentration ( $\left.4000 \mathrm{mg} \mathrm{L}^{-1}\right)$, depending on season. Therefore, this study suggests that there are species-specific differences with respect to the degree of easiness/difficulty of rooting of cuttings amongst species in different seasons.

\section{Conclusions}

The current study presents the development of vegetative propagation protocols for the Cretan local endemics $L$. minoana subsp. minoana and $S$. hirta which have potential ornamental and medicinal value. The 
concentration of $2000 \mathrm{mg} \mathrm{L}^{-1} \mathrm{IBA}$ is the optimum for rooting the cuttings of $L$. minoana subsp. minoana at $85 \%$ within 40 days and $4000 \mathrm{mg} \mathrm{L}^{-1} \mathrm{IBA}$ was found appropriate for $S$. hirta cuttings at $50 \%$ within 15 days. The rooting rates for $L$. minoana subsp. minoana cuttings treated with $2000 \mathrm{ppm}$ were above standards to allow possible commercial application in the ornamental industry. The respective percentage of rooting for $S$. hirta was almost marginal (50\%) for commercialization and further experimentation is necessary.

The growth of human needs and the concomitant commercial trade to date trigger the demand of new ornamental plants and new natural medicinal products. The sustainable utilization of the two Cretan endemics studied herein provides new inputs for the ornamental and pharmaceutical industry, given the overexploitation and direct marketing of wild phytogenetic resources in the horticultural sector (Krigas et al., 2014, 2017; Menteli et al., 2019) and the cosmetic-medicinal sector (Joshee et al., 2013; Grigoriadou et al., 2020). Under this perspective, it is imperative to urgently domesticate many wild plant species and introduce them into sustainable cultivation systems in order to avoid the depletion of phytogenetic resources. This is an important conservation strategy alleviating the effect of harvesting from the wild populations for satisfaction of commercial needs, allowing for or facilitating at the same time the long-term sustainable use of the phytogenetic resources and their steady supply.

\section{Authors' Contributions}

Conceptualization: K.G., N.K., E.M. and G.T.; Data curation: K.G., N.K. and V.S.; Formal analysis: K.G., N.K. and V.S.; Funding acquisition: K.G., N.K. and G.T.; Investigation: K.G. and V.S.; Methodology: K.G., N.K. and V.S.; Supervision: K.G. and E.M.; Validation: K.G., N.K., E.M. and G.T.; Visualization: K.G., V.S. and N.K.; Writing - original draft preparation: K.G., V.S., N.K. and G.T.; Writing - review and editing: K.G., N.K. and G.T.; Project administration: K.G. and G.T. All authors read and approved the final manuscript.

\section{Acknowledgements}

This research has been co-financed by the European Regional Development Fund of the European Union and Greek national funds through the Operational Program Competitiveness, Entrepreneurship and Innovation, under the call RESEARCH - CREATE - INNOVATE (project code: T1E $\Delta$ K-05380, MIS: 5030878, acronym: PRECISE-M) entitled 'Conservation and sustainable utilization of rare threatened endemic plants of Crete for the development of new products with innovative precision fertilization'.

\section{Conflict of Interests}

The authors declare that there are no conflicts of interest related to this article.

\section{References}

Ahern J (2013). Urban landscape sustainability and resilience: the promise and challenges of integrating ecology with urban planning and design. Landscape Ecology 28:1203-1212. https://doi.org/10.1007/s10980-012-9799-Z

Antrop M (2006). Sustainable landscapes: contradiction, fiction or utopia? Landscape and Urban Planning 75:187-197. https://doi.org/10.1016/j.landurbplan.2005.02.014

Barth JG (2020). Limestone and calcium in plants. At: Soin de la Terre. Retrieved 2020 May 11 from https://www.soinde-la-terreorg 
Beck T (2013). Principles of ecological landscape design. Island Press, Washington DC pp 107-124.

Beemnet MK, Solomon AM (2012). Effect of cutting position and rooting hormone on propagation ability of stevia (Stevia rebaudiana Bertoni). The African Journal of Plant Science and Biotechnology 6:5-8.

Beisheim K, Otte A (2017). Evaluating the ornamental value of the Caucasian flora in Georgia. Tuexenia 37:33-354. https://doi.org/10.14471/2017.37.008

Bewley JD, Black M (1994). Seeds: Physiology of development and germination. Plenum Press (4 ${ }^{\text {th }}$ ed), New York, pp 420.

Calhoun S (2012). Designer plant combinations: 105 Stunning gardens using six plants or fewer. Storey Publishing, USA, pp 240.

Cantor M, Erzsebet B, Zaharia A (2009). Scutellaria genus - possibilities for use of species as floral and medicinal crop. Journal of Plant Development 16:55-59.

Cerabolini B, Ceriani RM, Caccianiga M, De Andreis R, Raimondi B (2003). Seed size, shape and persistence in soil: a test on Italian flora from Alps to Mediterranean coasts. Seed Science Research 13:75-85. DOI: https://doi.org/10.1079/SSR2002126

Christopoulou C, Graikou K, Chinou I (2008). Chemosystematic value of chemical constituents from Scabiosa hymettia (Dipsacaceae). Chemistry \& Biodiversity 5:318-323. https://doi.org/10.1002/cbdv.200890029

Cole IB, Farooq FT, Murch SJ (2009). Protocols for establishment of an in vitro collection of medicinal plants in the genus Scutellaria. Methods in Molecular Biology 547:155-165. https://doi.org/10.1007/978-1-60327-287$2 \_13$

Cole IB, Saxena PK, Murch SJ (2007). Medicinal biotechnology in the genus Scutellaria. In Vitro Cellular and Developmental Biology - Plant 43(4):318-327. https://doi.org/10.1007/s11627-007-9055-4

Cristaudo A, Catara S, Impelluso C (2015). Conservation of native germplasm of the Mediterranean Region: ecological characterization of Sicilian flora species for sustainable use. In: Mariotti M, Magrini S (Eds). Conservation of threatened species: activities and collaborations within the network. RIBES Series 1, RIBES, pp 53-56.

Csonthos P, Tamas J, Balogh L (2007). Thousand-seed weight records of species from the flora of Hungary, II. Dicotyledonopsida. Studia Botatina Hungarica 38:179-189.

Cui XH, Chakrabarty D, Lee EJ, Paek KY (2010). Production of adventitious roots and secondary metabolites by Hypericum L. in a bioreactor. Bioresource Technology 101(12):4708-4716. https://doi.org/10.1016/j.biortech.2010.01.115

De Almeida MR, Aumond JRM, Da Costa CT, Schwambach J, Ruedell CM, Correa LR, ... Fett-Neto AG (2017). Environmental control of adventitious rooting in Eucalyptus and Populus cuttings. Trees 31:1377-1390. https://doi.org/10.1007/s00468-017-1550-6

Dee LE., Cowles J, Isbell F, Pau S, Gaines SD, Reich PB (2019). When do ecosystem services depend on rare species? Trends in Ecology \& Evolution 34(8):746-758. https://doi.org/10.1016/j.tree.2019.03.010

Denaxa NK, Vemmos SN, Roussos PA (2012). The role of endogenous carbohydrates and seasonal variation in rooting ability of cuttings of an easy and a hard to root olive cultivars (Olea europaea L.). Scientia Horticulturae 143:1928. https://doi.org/10.1016/j.scienta.2012.05.026

Elhaak MA, Matter MZ, Zayed MA, Gad DA (2015). Propagation principles in using indole-3-butyric acid for rooting rosemary (Rosmarinus officinalis) stem cuttings. Journal of Horticulture 2:1. https://doi.org/10.4172/23760354.1000121

Ferreira BGA, Zuffellato-Ribas KC, Wendling I, Koehler HS, Nogueira AC (2010). Miniestaquia de Sapium glandulatum (Vell.) Pax com o uso de ácido indol butírico e ácido naftaleno acético [Mini-cuttings of Sapium glandulatum (Vell.) Pax using indole butyric acid and naphthalene acetic acid]. Ciência Florestal 20(1):19-31. https://doi.org/10.5902/198050981758

Frischie S, Fernandez-Pascual E, Ramirez CG, Toorop P, Gonzalez MH, Jimenez-Alfaro B (2018). Hydrothermal thresholds for seed germination in winter annual forbs from old-field Mediterranean landscapes. Plant Biology 21(3):449-457. https://doi.org/10.1111/plb.12848

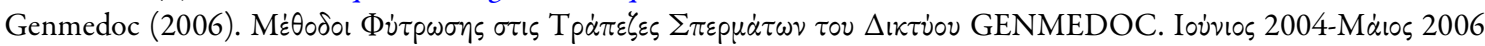
[Germination methods in the seed banks of the GENMEDOC network. June 2004-May 2006].

Getter KL, Rowe DB (2008). Selecting plants for extensive green roofs in the United States. Extension Bulletin E-3047, Michigan State University, USA, pp 9.

Greenfeild J, Davis JM (2004). Skullcap (Scutellaria laterifolia L.). Medicinal herb production guide. Retrieved 2006 July 12 from http://www.naturalmedicinesofnc.org 
Grigoriadou K, Krigas N, Sarropoulou V, Papanastasi K, Tsoktouridis G, Maloupa E (2019). In vitro propagation of medicinal and aromatic plants: the case of selected Greek species with conservation priority. In Vitro Cellular \& Developmental Biology 55(6):635-646. https://doi.org/10.1007/s11627-019-10014-6

Grigoriadou K, Moré E, Zapušek A, Cortegano M, Carmody K, Argyropoulos D (2020). EIP-AGRI focus group plantbased medicinal and cosmetic products. Mini paper 1. Main actors, markets and collaboration of MAPs value chain. The Agricultural European Innovation Partnership (EIP-AGRI) Service Point Publications (funded by the European Commission), July 2020, pp 1-10. https://ec.europa.eu/eip/agriculture/sites/agrieip/files/fg35_mp1_mainactorsmarketscollaboration_2020_en.pdf

Heo HJ, Kim D, Choi SJ, Shin DH, Lee CY (2004). Potent inhibitory effect of flavonoids in Scutellaria baicalensis on amyloid $\beta$ Protein-induced neurotoxicity. Journal of Agricultural and Food Chemistry 52(13):4128-4132. https://doi.org/10.1021/jf049953x

Hoover BK (2018). Auxin drench treatment improves Salvia 'Blue Hill' and Scabiosa 'Pink Mist' rooting. Horticulture and Crop Science, CAL POLY: College of Agriculture, Food \& Environmental Sciences, IPPS Western Region Conference. https://doi.org/10.13140/RG.2.2.35695.69283

Iapichino G, Arnone C, Bertolino M, Amico Roxas U (2006). Propagation of three Thymus species by stem cuttings. Acta Horticulturae 723(723):411-414. https://doi.org/10.17660/ActaHortic.2006.723.57

Joshee N, Patrick TS, Mentreddy SR, Yadav AK (2002). Skullcap: Potential medicinal crop. In: Janick J, Whipkey A. (Eds). Trends in new crops and new uses, ASHS Press, Alexandria, VA, pp 22-30.

Joshee N, Tascan A, Medina-Bolivar F, Parajuli P, Rimando AM, Shannon DA, ... Adelberg JW (2013). Scutellaria: Biotechnology, phytochemistry and its potential as a commercial medicinal crop. In: Chandra S, Lata H, Varma A (Eds). Biotechnology for medicinal plants. Chapter 3. Springer-Verlag, Berlin, Heidelberg pp 69-99. https://doi.org/10.1007/978-3-642-29974-2_3

Krigas N, Maloupa E (2008). The Balkan Botanic Garden of Kroussia, Northern Greece: a garden dedicated to the conservation of native plants of Greece and the Balkans. Sibbaldia: The Journal of Botanic Garden Horticulture 6:9-27. https://doi.org/10.23823/Sibbaldia/2008.33

Krigas N, Menteli V, Vokou D (2014). The electronic trade in Greek endemic plants: biodiversity, commercial and legal aspects. Economic Botany 68:85-95. https://doi.org/10.1007/s12231-014-9264-9

Krigas N, Mouflis G, Grigoriadou K, Maloupa E (2010). Conservation of important plants from the Ionian Islands at the Balkan Botanic Garden of Kroussia, N Greece using GIS to link the in situ collection data with plant propagation and ex situ cultivation. Biodiversity and Conservation 19(12):3583-3603. https://doi.org/10.1007/s10531010-9917-7

Krigas N, Panagiotidou M, Maloupa E (2017). Incorporating biogeographical principles in horticulture: design and creation of the Ionian islands unique rock garden in Thessaloniki, Greece. Sibbaldia: The Journal of Botanic Garden Horticulture 15:129-146. https://doi.org/10.23823/Sibbaldia/2017.228

Kupferschmid AD, Stampfli A, Newbery DM (2000). Dispersal and microsite limitation in an abandoned calcareous grassland of the southern Prealps. Folia Geobotanica 35:125-141. https://doi.org/10.1007/BF02803092

Maloupa E, Grigoriadou K, Zervaki D, Papanastassi K (2005). Management of the Balkan native flora for sustainable floricultural commercial use. Acta $\quad$ Horticulturae https://doi.org/10.17660/ActaHortic.2005.683.21

Maloupa E, Krigas N, Grigoriadou K, Lazari D, Tsoktouridis G (2008). Conservation strategies for native plant species and their sustainable exploitation: case of the Balkan Botanic Garden of Kroussia, N. Greece. In: Teixeira da Silva JA (Ed). Floriculture, ornamental and plant biotechnology: Advances and topical issues. Volume 4. Global Science Books (1st ed), Isleworth, UK, pp 37-56.

Menteli V, Krigas N, Avramakis E, Turland N, Vokou D (2019). Endemic plants of Crete in electronic trade and wildlife tourism: current patterns and implications for conservation. Journal of Biological Research-Thessaloniki 26:10. https://doi.org/10.1186/s40709-019-0104-Z

Morgan A, Pearson B (2018). Florida medicinal garden plants: Skullcap (Scutellaria spp.). Department of Agriculture, UF/IFAS Extension Service, University of Florida, IFAS, Florida, USA, ENH 1300. Retrieved 2020 December 5 from http://edis.ifas.ufl.edu

O’Brien J (2013). Seed germination and seed bank of Scutellaria species. BSc Thesis, Eastern Illinois University, Charleston, Illinois, USA. http://thekeep.eiu.edu/bio_students 
Panayotova LG, Ivanova TA, Bogdanova YY, Gussev CV, Stanilova MI, Bosseva YZ, ... Stoeva TD (2008). In vitro cultivation of plant species from sandy dunes along the Bulgarian Black Sea Coast. Phytologia Balcanica $14(1): 119-123$.

Papafotiou M, Kanellou E, Economou G (2017). Integrated design and management of vegetation at archaeological sites to protect monuments and enhance the historical landscape. Acta Horticulturae 1189:1-10. https://doi.org/10.17660/ActaHortic.2017.1189.1

Parađiković N, Zeljković S, Tkalec M, Vinković T, Dervić I, Marić M (2013). Influence of rooting powder on propagation of sage (Salvia officinalis L.) and rosemary (Rosmarinus officinalis L.) with green cuttings. Poljoprivreda 19(2):10-15. https://hrcak.srce.hr/112543

Paulus D, Valmorbida R, Paulus E (2016). Ácido indolbutírico na propagação vegetativa de alecrim [Indolbutyric acid in the vegetative propagation of rosemary]. Horticultura Brasileira 34(4):520-528. https://doi.org/10.1590/s0102-053620160411

Paulus D, Valmorbida R, Toffoli E, Paulus E (2014). Propagação vegetativa de Aloysia triphylla (L'Hér.) Britton de acordo com IBA e comprimento de estacas [Vegetative propagation of Aloysia triphylla (L'Hér.) Britton according to IBA and length of cuttings]. Revista Brasileira de Plantas Medicinais 16(1):25-31. https://doi.org/10.1590/S1516-05722014000100004

Pijut PM, Wowste KE, Michler CH (2011). Promotion of adventitious root formation of difficult-to-root hardwood tree species. Horticultural Reviews 38:213-251. https://doi.org/10.1002/9780470872376.ch6

Sabatino L, D’Anna F, Iapichino G (2014). Cutting type and IBA treatment duration affect Teucrium fruticans adventitious root quality. Notulae Botanicae Horti Agrobotanici Cluj-Napoca 42(2):478-481. https://doi.org/10.15835/nbha.42.2.9611

Sari D, Karaşah B (2015). Green roofs and xeriscape planting that contribute to sustainable urban green space. In: Proceedings of the ICSAUD 2015: $17^{\text {th }}$ International Conference on Sustainable Architecture and Urban Design, Kyoto, Japan, 17(11): 962-966.

Schneider A, Fusco M, Bousselot J (2014). Observations on the survival of 112 plant taxa on a green roof in a semi-arid climate. Journal of Living Architecture 1:10-30. https://doi.org/10.6084/m9.figshare.11977821

SID-KEW (Seed Information Database of Royal Botanic Gardens Kew). Wakehurst Place, Kew Gardens, London, UK. Retrieved 2020 March 25 from https://data.kew.org/sid/

Similien A (2009). Effect of shade, irrigation and nutrients on dry matter yield and flavonoid content in American skullcap. MSc Dissertation, Department of Agronomy and Soils, Auburn University, Alabama, USA. http://hdl.handle.net/10415/1647

Tascan A, Adelberg JW, Rimando AM, Tascan M, Joshee N, Yadav AK (2010). Hyperhydricity and flavonoid content of Scutellaria species in vitro on polyester-supported liquid culture systems. HortScience 45(11):1723-1728. https://doi.org/10.21273/HORTSCI.45.11.1723

Venugopal CK, Raviprasad Sajjan M, Sharma Y, Yashavantakumar KH (2018). Effect of different concentrations of indole-3-butyric acid (IBA) on rooting of rosemary (Rosmarinus officinalis) under mist house environment. International Journal of Chemical 6(3):1524-1526. https://www.chemijournal.com/archives/2018/vol6issue3/PartV/6-3-146-131.pdf

Vlachou G, Papafotiou M, Akoumianaki A, Bertsouklis KF (2019). Propagation of Scabiosa hymettia (Boiss. \& Spruner) by stem cuttings. Acta Horticulturae 1242:763-766. https://doi.org/10.17660/ActaHortic.2019.1242.113

Wang J, Liu K, Xu D, Wang Q, Bi K, Song Y, ... Zhang L (2013). Rapid micropropagation system in vitro and antioxidant activity of Scabiosa tschiliensis Grunning. Plant Growth Regulation 69(3):305-310. https://doi.org/10.1007/s10725-012-9765-4

Wendling I, Trueman SJ, Xavier A (2014). Maturation and related aspects in clonal forestry-part II: reinvigoration, rejuvenation, and juvenility maintenance. New Forests 45:473-486. https://doi.org/10.1007/s11056-014$9415-y$ 
OPEN ACCESS

(c) (2)

The journal offers free, immediate, and unrestricted access to peer-reviewed research and scholarly work. Users are allowed to read, download, copy, distribute, print, search, or link to the full texts of the articles, or use them for any other lawful purpose, without asking prior permission from the publisher or the author.

License - Articles published in Notulae Botanicae Horti Agrobotanici Cluj-Napoca are Open-Access, distributed under the terms and conditions of the Creative Commons Attribution (CC BY 4.0) License. (C) Articles by the authors; UASVM, Cluj-Napoca, Romania. The journal allows the author(s) to hold the copyright/to retain publishing rights without restriction. 